\title{
Animal Update in the Great Rowshan Circus of Bangladesh
}

\author{
Ashraful Kabir* \\ Department of Biology, Saidpur Cantonment Public College, Nilphamari, Bangladesh
}

*Corresponding Authors: Ashraful Kabir, Department of Biology, Saidpur Cantonment Public College, Nilphamari, Bangladesh

\begin{abstract}
The Great Rowshan Circus' is one of the oldest and renowned circus team of Bangladesh. This team is performing their various acts with animals from 1965. In this satellite world, this type of circus is totally different to the people. Most people like it and get enjoy with their family. For entertaining all sorts of people the trained workers of the circus team show their unbelievable acts. After seeing this circus activities several times and discussing with the workers many information on animals were collected. At present, this team has only 5 types of animals- Domestic Horse, Asian Elephant (Elephas maximus), Rhesus Monkey (Macaca mulatta), Japanese Spitz, and Asian Black Bear (Ursus thibetanus), and In the year 2013, they had 8 types of animals. Due to course of time, maximum were died for their old age, some could not cope with different environment, and some were escaped from the cage. In addition, dysentery and colic pain were the common ailments of those animals. Japanese Spitz and Horse are domestic whereas Rhesus Monkey, Asian Black Bear, and Asian Elephant are wild. The food items of these animals are good but the cage size of bear needs to enlarge. This study was conducted in the year 2019.
\end{abstract}

Keywords: Animal update; Rowshan Circus; Cultural tradition; Wildlife Act; Saidpur; Bangladesh.

\section{INTRODUCTION}

From a Greek word 'krikos' meaning circle/ring the word circus has been coined. A circus team is considered a travelling company of performers that may include clowns, acrobats, acts, music, hoppers, tightrope walkers, jugglers, unicyclists, and animal acts. The dimension of circus was adopted by Philip Astley to enable a horse rider in circus and he added tumblers, tightrope walkers, jugglers, performing dogs, and a clown and finally created the modern circus first. In England, circuses were often a combination of the circus, the menagerie and the variety theatre, where animals such as lion and elephant from time to time appeared in the ring (Wikipedia.org). In the year 1928, a great movie named 'The Circus', directed by Sir Charlie Chaplin and others were Circus (1936), The Greatest Show on Earth (1952), The Big Circus (1959), Jumbo Circus (1962), Water for Elephants (2011), and Big Fish (2003). Bangladesh has a very long history of the traditional circus. Once it was very popular for entertaining different levels of people. At least 80-100 people work in a big circus team. Many of them are involved in circus from their childhood. At present, the circus team cannot earn money as they got before because of ongoing satellite culture. Sometimes the owner sacrifices money to run his circus team. As a whole, the circus tradition is now under threat. It will not survive if no proper initiatives have been taken by the government (Abir Abdullah). Chinese latim balance, fire dance, and roller skating on the table are among the most enjoyable acts by the Rowshan Circus of Bangladesh (Circus in the City, Daily Star, 2011). The objective of this study is to observe the animal update of 'The Great Rowshan Circus' of Bangladesh.

\section{MATERIALS AND Methods}

\subsection{Rowshan Circus of Bangladesh}

This circus is performing their acts all the year round except any religious festival. Circus team is like nomads; they are performing with their family day after day with all troops.

\subsection{Domestic, pet, and Wild Animals}

From the poachers, illegal wildlife traders, snake charmers, and gypsies are involved with supplying of the animals in circus team. They catch wild animals and sell with very few amount of money. Domestic animals like horse are available in any market of Bangladesh. Asian Elephant has been hired from Sylhet at the rate of 3000 taka daily. 


\subsection{Animal Trainer}

An animal trainer named 'Amar Pandey' is engaged with the animals. When training comes, animals are just frightened by the trainer for using whip and hook. Some animal attack mainly bite of bear was common for the animal trainer. Bear, monkey, and dogs are vaccinated here.

\section{Results}

Table1. Behaviour of circus animals

\begin{tabular}{|l|l|}
\hline Animals & Behaviour \\
\hline Domestic Horse & Biting, threat kick \\
\hline Asian Elephant & $\begin{array}{l}\text { Sleep only 2-3 hours, spend most the time for food, } \\
\text { brain is more ridged so elephants are brilliant, it attacks } \\
\text { for mistreating }\end{array}$ \\
\hline Rhesus monkey & $\begin{array}{l}\text { IQ is more than 174, it takes upto 45 kg load, carries } \\
\text { bacterium and virus, bite creates rabies }\end{array}$ \\
\hline Japanese Spitz & For pet, this is docile \\
\hline Asian Black Bear & $\begin{array}{l}\text { Apex predator, national animals of Finland, intelligent } \\
\text { animal, good smell power, show carnivoral lethargy, } \\
\text { can sleep for a long time }\end{array}$ \\
\hline
\end{tabular}

Table2. Showing the status of the circus animals

\begin{tabular}{|c|c|c|c|c|c|c|c|}
\hline $\begin{array}{l}\text { English } \\
\text { name }\end{array}$ & Scientific name & $\begin{array}{l}\text { Collected } \\
\text { from }\end{array}$ & $\begin{array}{l}\text { Age } \\
\text { and sex }\end{array}$ & $\begin{array}{l}\text { Cage size } \\
(\mathrm{LxWxH})\end{array}$ & $\begin{array}{l}\text { Bangladesh } \\
\text { status }\end{array}$ & $\begin{array}{l}\text { Global } \\
\text { status }\end{array}$ & Distribution \\
\hline $\begin{array}{l}\text { Domestic } \\
\text { Horse }\end{array}$ & - & $\begin{array}{l}\text { Buy from } \\
\text { market, } \\
\text { Bangladesh }\end{array}$ & $\begin{array}{l}1 \text { year, } \\
\text { female }\end{array}$ & Open & - & $\mathrm{D} / \mathrm{P}$ & $\mathrm{AC}$ \\
\hline $\begin{array}{l}\text { Asian } \\
\text { Elephant }\end{array}$ & $\begin{array}{l}\text { Elephas maximus } \\
\text { L. } 1758\end{array}$ & $\begin{array}{l}\text { Hired from } \\
\text { Sylhet, } \\
\text { Bangladesh }\end{array}$ & $\begin{array}{l}40 \\
\text { years, } \\
\text { male }\end{array}$ & Open & $\mathrm{CR}$ & EN & MEF \\
\hline $\begin{array}{l}\text { Rhesus } \\
\text { Monkey }\end{array}$ & $\begin{array}{l}\text { Macaca mulatta } \\
\text { Zimmermann } \\
1780\end{array}$ & $\begin{array}{l}\text { Buy from a } \\
\text { monkey } \\
\text { charmer of } \\
\text { Dinajpur, } \\
\text { Bangladesh }\end{array}$ & $\begin{array}{l}4 \text { years, } \\
\text { female }\end{array}$ & $6^{\prime} \times 4^{\prime} \times 4^{\prime}$ & VU & $\mathrm{LC}$ & \\
\hline $\begin{array}{l}\text { Japanese } \\
\text { Spitz }\end{array}$ & - & $\begin{array}{l}\text { Collected } \\
\text { from Nepal }\end{array}$ & $\begin{array}{l}13 \\
\text { years, } \\
\text { male- } \\
\text { female }\end{array}$ & $\begin{array}{l}5^{\prime} \times 4^{\prime} \times 4^{\prime}, \\
2^{\prime} \times 4^{\prime} \times 2^{\prime}\end{array}$ & - & $\mathrm{D} / \mathrm{P}$ & $\mathrm{W}$ \\
\hline $\begin{array}{l}\text { Asian } \\
\text { Black } \\
\text { Bear }\end{array}$ & $\begin{array}{l}\text { Ursus thibetanus } \\
\text { G. Couvier } 1823\end{array}$ & $\begin{array}{l}\text { Imported } \\
\text { from India }\end{array}$ & $\begin{array}{l}11 \\
\text { years, } \\
\text { male }\end{array}$ & $6^{\prime} \times 4^{\prime} \times 4^{\prime}$ & $\mathrm{CR}$ & VU & MEF \\
\hline
\end{tabular}

Red Data Book, IUCN Bangladesh (2015); D/P=Domestic/Pet; AC=Asian Countries; EN=Endangered; $W=$ Widely distributed $; M E F=$ Mixed Evergreen Forest; VU=Vulnerable; LC=Least Concern; CR=Critically

Endangered

Table3. Food serving chart by the animal trainer

\begin{tabular}{|l|l|l|}
\hline Animals & Amount of food (daily) & Feeding time \\
\hline $\begin{array}{l}\text { Domestic } \\
\text { Horse }\end{array}$ & Gram, Wheat, rice husk=5 kg & $2 \mathrm{pm}, 8 \mathrm{pm}, 12 \mathrm{pm}$ \\
\hline Asian Elephant & $\begin{array}{l}\text { Rice, wheat, Husk=not maintained, Banana tree 20-25 } \\
\text { pieces }\end{array}$ & From noon to afternoon \\
\hline $\begin{array}{l}\text { Rhesus } \\
\text { Monkey }\end{array}$ & Rice, Milk, Banana=0.5 kg & $9 \mathrm{am}, 1 \mathrm{pm}, 12 \mathrm{pm}$ \\
\hline Japanese Spitz & Rice, Fish, Meat, Milk=2 kg & $9 \mathrm{am}, 1 \mathrm{pm}, 12 \mathrm{pm}$ \\
\hline $\begin{array}{l}\text { Asian Black } \\
\text { Bear }\end{array}$ & Rice, Milk, Bread, Honey=6 kg & $12 \mathrm{am}, 12 \mathrm{pm}$ \\
\hline
\end{tabular}

\section{DISCUSSION}

Human being dominates all living creatures in this world that directly influence others (Coe, 1999). Ancient movies on circus actually focused the condition of animals. World greatest animal trainer 'Melvin Koontz' who was a lion trainer and 'Axel Gautier' was an elephant trainer and he died by his 
elephant in Florida in the year 1993, 5 May (incident(s), Lawsuit filed). A report showed that from 1978 to 2001 most of the circus animal incidents were happened in Florida and New York, then California and Moscow. Only 2 incidents were recorded in England and Pennsylvania of the total incidents during performing the circus or handling of the animals to people and 6 animal trainers killed by elephants, 3 bit by bear, 16 injured, 3 animal attacked were observed. On the other hand, this report suggested that 8 elephants, 2 bears, 1 Arabian horse, and 1 donkey were killed by police due to threatened for human life in circus time (updated news, 2001). Both Asian and African Elephants are legally banned by CITES in 1990 (updated March, 2001). From an another report, most elephant attacks were found in USA, Florida (10) and less (1) in India and Bangladesh during the year from 1950 to 2005, where 18 people killed by elephant, 15 elephants killed by people for attacking to people, 1 lion killed due to elephants attack, 4 complete attacks, and 26 people were injured during performing in circus (Incident(s), lawsuit filed). Issac A. Van Amburgh entered a cage with several big cats in 1833, and is generally considered first wild animal trainer in American Circus history. Mabel Stark was a famous female tiger-tamer.

\section{CONCLUSION}

In circus team, the animals are tortured all day long especially in their training session. They are forced to do something by whipping and hooking. These acts are completely disobeyed the animal rights of the world. We should show love to animals and stop cruelty (Kabir, 2016). This article suggests that most of the animal attacks were happened by elephant, bear, horse, and donkey. We should not irritate these animals when they take rest or during playing. Through better understanding (behaviour) about these animals, we can overcome such attacks. Newly renewed 'The Wildlife Act of Bangladesh' does not allow the use of wild animals in circus or any other purposes. Ferocious animals are naturally dangerous and totally prohibited in circus. On the basis of public demand or for different testament, we can use only domestic and pet animals in circus.

\section{REFERENCES}

[1] Abir Abdullah, Circus in Bangladesh.

[2] Circus and ride elephant. See-incident; incidents; lawsuits filed; lawsuit file-child's family Circus in the city

[3] Coe, J. C. 1999. Increasing affiliation behavior between zoo animals and zoo visitors. AZA Convention Proceedings, American Zoo and Aquarium Association, Silver Spring, pp. 216-220.

[4] Kabir, M. A. 2013. Circus tradition of Bangladesh and fate in its animals. South Pacific Journal of Pharma and Bio Science. (1): 51-57.

[5] Kabir, M. A. 2016. Human cruelty and love to animals. International Journal of Research Studies in Zoology. 2(2): 1-8.

[6] Updated March, 2001. Animals and people at the circus: accidents, attacks, animal abuse, and other incidents. The Human Society of the United States, 2100 L Street, NW, Washington DC.

[7] Red List of Bangladesh, 2015. IUCN-International Union for Conservation of Nature and Natural Resources. Bangladesh Country Office.

Citation: Ashraful Kabir " Animal Update in the Great Rowshan Circus of Bangladesh", International Journal of Research Studies in Zoology vol. 6, no. 1, pp. 20-22, 2020. Available: DOI: http://dx.doi.org/ 10.20431/2454-941X.0601004

Copyright: (c) 2020 Authors. This is an open-access article distributed under the terms of the Creative Commons Attribution License, which permits unrestricted use, distribution, and reproduction in any medium, provided the original author and source are credited. 